\title{
Evaluation of Non-adherence to Anti-tuberculosis Treatment at a DOTS Clinic in Malaysia
}

\author{
Kumarasamy Sakuntala ${ }^{1}$, Manghanmal Ashah ${ }^{2}$, Sivanandy Palanisamy ${ }^{3 *}$ and \\ Karthikayini Krishnasamy ${ }^{1}$ \\ 'Department of Nursing, University Malaya Medical Centre, Kuala Lumpur, Malaysia; \\ sakuntala@ummc.edu.my, karthikayini@ummc.edu.my \\ ${ }^{2}$ Program leader, BSc (Hons) Nursing (Post Reg,) MAHSA University, Saujana Putra Campus, \\ Kuala Langat, Selangor, Malaysia; ashah@mahsa.edu.my \\ ${ }^{3}$ Department of Pharmacy Practice, School of Pharmacy, International Medical University, Kuala \\ Lumpur-57000, Malaysia; sivapalanisamy@yahoo.co.in
}

\begin{abstract}
Adherence to tuberculosis treatment is vital to prevent and control the disease from further progression into multiple complications. However, due to many reasons the adherence level is very poor among the tuberculosis patients. This study was aimed to assess the knowledge and perception of tuberculosis patients on anti-tubercular therapy and determine the factors that involved in non-compliance to tuberculosis treatment. The study was carried out for a period of 4 months at the DOTS clinics, among the patients who availed anti-tuberculosis treatment for at-least 2 consecutive months. A structured, validated questionnaire was used to gather relevant information pertaining to the study objectives. Among the 171 respondents, most (39.8\%) were between 21 to 39 years old, 55.6\% were male, $81 \%$ with secondary level of education and $48 \%$ had diploma level of education. Majority of the respondents were Malay (40.9\%), Chinese (23.4\%), Indian (22.2\%), and others $(13.5 \%)$. The mean percentage score of respondents on knowledge, attitude, and perception on tuberculosis treatment were $58.9 \pm 19.3$ and $44.2 \pm 9.4$, respectively. There were no significant differences in the scores on knowledge, attitude, and perception on tuberculosis with respondents' age, sex, education, ethnicity, marital and employment status. The knowledge, attitude, and perception towards TB treatment among the patients who regularly visit the DOTS clinics were moderate to good. However, there were many defaulters in the current TB therapy as many patients did not follow-up their treatment schedule and drop out in the early phase/month of the TB course due to lack of support from family and friends, and also the influence of social and community factors. These barriers need to be addressed in an emergency basis for the benefit of patient community.
\end{abstract}

Keywords: Adherence, Bacteria, DOTS clinic, Medication, Tuberculosis

\section{Introduction}

Tuberculosis (TB) is an important health problem in the world and the World Health Organization (WHO) estimates TB will be the leading causes of death and disability among the people living in rural and low economic group. As per WHO, TB related mortality will be 3 million annually and by 2020 the TB related death toll will reach more than one billion. Astonishingly, TB control is very poor in developing and under-developed countries where more than $80 \%$ of the cases are related to faster rate of re-emergence of the disease. It mainly impacts low-income countries where resources for healthcare management are severely restricted ${ }^{1-3}$.

Adherence to TB treatment is very challenging as the duration of tuberculosis treatment is long and lot of

${ }^{*}$ Author for correspondence 
medications related complications. Adherence to long term TB treatment is highly essential to obtain effective treatment outcome and to prevent $\mathrm{TB}$ medication resistant bacilli strain. Non-adherence to TB treatments has several consequences especially it affects the patient's socioeconomic and health conditions. Multi-drugresistant TB (MDR-TB) is one of serious problem among the tuberculosis patients that puzzling the global TB control program. For instance, the interruption during long term TB treatment even a single day of interruption has developed MDR-TB, which are 13 times higher than among those who did not interrupt their treatment ${ }^{4}$.

Compared to many other Asian and African countries, Malaysia has proved its efficiency in managing the TB outbreak several times. TB infection in Malaysia was a serious health problem with significant increasing number of infected persons, and high mortality rate. However, due to the implementation of preventive measure and effective solution by the government, the number of TB cases and deaths were reduced significantly. It shown a positive impact on reduction in the number of TB cases from 1970 s to $1992^{5}$. However, there was an outbreak starting from 1992, the reported cases and the mortality rate has increased gradually. As per the Ministry of Health 2011 Annual Report, there were 19,337 TB cases with $1,557 \mathrm{~TB}$ related deaths in the country. Hence, it is vital to examine the route case of the problem and identify the challenges in the implementation of TB program. It would help in achieving WHO goal of full elimination of TB in the world by $2050^{6}$.

Adherence to TB treatment is considerably less among the local population as several studies mentioned that there were lack of knowledge, attitude, and perception on disease, transmission of infection and treatment among TB patients. In, University Malaya Medical Center (UMMC), the numbers of patients who were nonadherent to TB treatment increasing every year. Moreover, patients do not finish their treatment course fully and just ignore the treatment regimen. Hence, a study was aimed to assess the knowledge and perception of TB patients on TB treatment, factors that involved in non-compliance to TB treatment and, analyse the relationship between socio-demographic characteristics with knowledge and perception on TB treatment.

\section{Methodology}

\subsection{Study Design and Setting}

A quantitative descriptive cross-sectional study was carried out at the DOTS clinic and medical wards of a 1100 bed tertiary care hospital in Kuala Lumpur. The study was carried out for a period of 4 months from August to November 2019.

\subsection{Study Population}

All TB patients of either sex and above the age of 18, any ethinic groups, alert, rationally and mentally stable, and receiving anti-tubercular therapy at the DOTS clinic for at-least 2 months' period and who are willing to participate in this study were included, as they are able to give informed consent and able to understand and answer the questions provided to complete the survey on their own. The study participants were selected from TB patients who visited DOTS clinic and medical wards by adopting convenience sampling method.

The total number of patients who visit the DOTS clinic per month were approx. 200-300, and the sample size for the study was calculated based on $95 \%$ confidence interval with a margin of error that does not exceed \pm 5 percent. The total sample were identified as 363 , for the finite population of approximately 2500 . However, due to the non-adherence to treatment, 171 were came for review and approached to participate in this study.

\subsection{Research Instrument}

A validated survey questionnaire was used in this study. It consists of 50 questions; Section-A consists of 6 questions on patients' demographics, Section-B consists of 12 questions to analyse respondents' knowledge on TB and, Section-C consists of 32 questions to analyse respondents' perception, attitude, and factors that contribute to TB medications non-adherence. This study questionnaire was validated among the faculty members and experts for its content's quality, readability, and reproducibility. 


\subsection{Reliability of the Questionnaire}

To check the reliability and internal consistency of the questionnaire, a pilot study was carried out using 30 participants, in which they were excluded from the actual study. After the pilot study, no amendments were made in the questionnaire. The internal consistency of the questionnaire was tested using Cronbach alpha, it was ranged from 0.76 to 0.89 and the overall internal consistency was observed at 0.82 during the pilot study.

\subsection{Data Collection and Analysis}

Self-administered questionnaire was distributed to participants during their visit to DOTS clinic and the data was collected immediately after their visit to clinic. Patients were briefed on how to fill the information regarding their experience on $\mathrm{TB}$ treatment in the questionnaire form. This was done to ensure the data was accurate and free of errors. The collected data was then tabulated and analysed using SPSS 25.0.

\subsection{Ethical Considerations}

Ethical permission was obtained from research ethical review committee of MAHSA University and UMMC during the research process (MREC ID NO: 20199187843). Consequently, consents and agreement from participants was sought before issuing questionnaires and other instruments which needed for the research. The maintenance of confidentiality, privacy and anonymity of patient's records were done during the research process.

\section{Results}

\subsection{Demographic Characteristics of Respondents}

There was a total of 171 respondents in this study. Most (39.8\%) of the respondents were between 21 to 39 years old, $55.6 \%$ were male, $81 \%$ had secondary level of education and $48 \%$ had diploma level of education. Most of the respondents were Malay (40.9\%), Chinese (23.4\%) and Indian (22.2\%) and others (13.5\%). Sixty-two percent respondents were married, $40.9 \%$ of respondents were unemployed. Among the working adults, 36.8\% were working in private sectors, around $11 \%$ each with government sector and self-employed. The demographic characteristics, education level and employment status of the respondents are presented in table 1 and 2 , respectively

Table 1. Demographic characteristics of the respondents $(\mathrm{n}=171)$

\begin{tabular}{|c|c|c|}
\hline Variable & Frequency & Percentage \\
\hline \multicolumn{3}{|l|}{ Age } \\
\hline Less than 20 years & 9 & 5.3 \\
\hline $20-29$ years & 33 & 19.3 \\
\hline 30 - 39 years & 35 & 20.5 \\
\hline $40-49$ years & 24 & 14 \\
\hline $50-59$ years & 29 & 17 \\
\hline 60 years and above & 41 & 24 \\
\hline \multicolumn{3}{|l|}{ Sex } \\
\hline Male & 95 & 55.6 \\
\hline Female & 76 & 44.4 \\
\hline \multicolumn{3}{|l|}{ Ethnic group } \\
\hline Malay & 70 & 40.9 \\
\hline Indian & 38 & 22.2 \\
\hline Chinese & 40 & 23.4 \\
\hline Others & 23 & 13.5 \\
\hline \multicolumn{3}{|l|}{ Marital status } \\
\hline Single & 62 & 36.3 \\
\hline Married & 106 & 62 \\
\hline Divorcee & 2 & 1.2 \\
\hline Separated & 1 & 0.6 \\
\hline
\end{tabular}

Table 2. Education level and working status of the respondents $(\mathrm{n}=171)$

\begin{tabular}{|c|c|c|}
\hline Variable & Frequency & Percentage \\
\hline Education level & & \\
\hline Primary & 6 & 3.5 \\
\hline Secondary & 81 & 47.4 \\
\hline Diploma & 48 & 28.1 \\
\hline Degree & 36 & 21.1 \\
\hline Employment status & & \\
\hline Government & 19 & 11.1 \\
\hline Private sector & 63 & 36.8 \\
\hline Self-employee & 19 & 11.1 \\
\hline Unemployed & 70 & 40.9 \\
\hline
\end{tabular}




\subsection{Assessment of Respondents' Knowledge, Attitudes, and Perception on TB Treatment}

There were 12 items in the knowledge section of the questionnaire. Answers for each item were coded as 1 for correct answer and 0 for incorrect answers. Hence, the individual knowledge score was ranged from 0 to 12 . For contributing factors, there were 32 items, again, the answers for each item were coded as 1 for positive response and 0 for negative response; the positive response include strongly agree and agree, whereas the negative response include strongly disagree, disagree and neutral. Hence, the individual contributing factors score ranged from 0 to 32 . The mean percentage results are shown in table 3 .

\subsection{Association Between Knowledge Score and Demographic Characteristics}

The skewness for both variables (knowledge and contributing factors) values are less than 2 and kurtosis value are less than 7. Hence, the distributions are normal. Since, attitude and contributing factors score was distributed normally, the associations between demographic characteristics were tested using parametric test one-way ANOVA for 2 groups. The results are shown in table 4 . There were no significant differences in knowledge and contributing factors by any of the demographic characteristics.

There were no significant differences in knowledge score by age $(\mathrm{p}=0.965)$, gender $(\mathrm{p}=0.611)$, education $(\mathrm{p}=0.512)$, ethnicity $(\mathrm{p}=0.178)$, marital status $(\mathrm{p}=0.936)$ and employment status $(\mathrm{p}=0.318)$. For age, the mean percentage score for those who between 20 to 29 years old $(60.35 \pm 20.73)$ was significantly higher compared to other age groups. The knowledge score among the gender and education showed not much difference in their knowledge level and it is not statistically significant. Among the respondents, Indians (53.28 \pm 21.53$)$ had comparatively less knowledge on TB educations compared to other races. No statistically significant difference in knowledge
Table 4. Comparison of knowledge and contributing factors scores with demographic characteristics

\begin{tabular}{|c|c|c|}
\hline Variable & Skewness & Kurtosis \\
\hline Knowledge & -0.303 & 0.140 \\
\hline Contributing factors & 0.762 & 3.181 \\
\hline
\end{tabular}

were observed with the level of education among all the respondents.

There were no statistically significant differences in knowledge on contributing factors were observed by age $(\mathrm{p}=0.842)$, gender $(\mathrm{p}=0.851)$, education $(\mathrm{p}=0.100)$, ethnicity $(\mathrm{p}=0.407)$, marital status $(\mathrm{p}=0.404)$ and employment status $(\mathrm{p}=0.476)$. The knowledge on contributing factors was high among the respondents who aged 60 years and above $(60.16 \pm 18.95)$. No difference in knowledge on contributing factors were observed between the sex, however the score was high among the degree holder $(47.13 \pm 11.55)$, other ethnic group $(47.28 \pm 7.194)$ and divorced (53.12 \pm 8.838$)$.

The comparison of positive and other responses for the individual items of the TB knowledge assessment questionnaire was carried out and the results are presented in table 5. Moreover, the comparison of knowledge of respondents on the contributing factors of $\mathrm{TB}$, its resistance and non-adherence to $\mathrm{TB}$ treatment also carried out, the data are presented in table 6 and 7.

\section{Discussion}

\subsection{Relationship with Demographic Factors and Knowledge on Adherence of TB Treatment}

TB is a communicable disease caused by different types of mycobacterium species. The prevalence and incidence of TB is high in people dwelling in rural and under-developed area as they do not come to the health clinics on time for treatment ${ }^{7-9}$. According to WHO, the incidences more in Asian and African countries. Even

Table 3. Mean percentage score of respondents on knowledge, attitude, and perception about TB treatment

\begin{tabular}{|c|c|c|c|c|}
\hline Variable & Mean $\% \pm$ SD & Median $(\mathrm{IQR})$ & Minimum & Maximum \\
\hline Knowledge & $58.9 \pm 19.3$ & $58.3(33.3)$ & 0 & 100 \\
\hline Attitude \& Perception & $44.2 \pm 9.4$ & $44.8(12.5)$ & 21.9 & 90.6 \\
\hline
\end{tabular}


Table 5. Comparison of positive and other responses for the individual items of the knowledge on Tuberculosis

\begin{tabular}{|c|c|c|c|}
\hline No & Items & Positive response $\mathbf{n}(\%)$ & Other responses $\mathrm{n}(\%)$ \\
\hline 1 & 'TB disease is caused by germ/bacteria' & $148(86.5)$ & $23(13.5)$ \\
\hline 2 & 'TB disease can be caused by tobacco smoking' & $63(36.8)$ & $108(63.2)$ \\
\hline 3 & $\begin{array}{l}\text { 'TB is transmitted by infectious droplet spread by infected person, } \\
\text { during coughing and sneezing' }\end{array}$ & $121(70.8)$ & $50(29.2)$ \\
\hline 4 & $\begin{array}{l}\text { 'TB can transmit through, sharing eating utensil, kissing and shaking } \\
\text { hand' }\end{array}$ & $52(30.4)$ & $119(69.6)$ \\
\hline 5 & $\begin{array}{l}\text { 'TB can be prevented from transmission by covering mouth and } \\
\text { nose during coughing and sneezing, appropriate sputum dropping, } \\
\text { opening windows in home and in car while traveling' }\end{array}$ & $136(79.5)$ & $35(20.5)$ \\
\hline 6 & $\begin{array}{l}\text { 'The main TB symptoms are cough }>2 \text { weeks, chest pain, heavy night } \\
\text { sweating, appetite loss, weight loss, extreme tiredness or fatigue and } \\
\text { coughing up blood with sputum' }\end{array}$ & $127(74.3)$ & $44(25.7)$ \\
\hline 7 & 'There is effective medical treatment for TB disease' & $124(72.5)$ & $47(27.5)$ \\
\hline 8 & 'If treated properly, TB disease is curable' & $123(71.9)$ & $48(28.1)$ \\
\hline 9 & $\begin{array}{l}\text { 'TB treatment is received in front of health care worker or somebody } \\
\text { assigned to observe the treatment for } 2 \text { months' }\end{array}$ & $97(56.7)$ & $74(43.3)$ \\
\hline 10 & $\begin{array}{l}\text { 'TB medication is taken in home while coming per month for drug } \\
\text { refill and check-up during continuation phase' }\end{array}$ & $114(66.7)$ & $57(33.3)$ \\
\hline 11 & $\begin{array}{l}\text { 'If develop any side effect cause by TB medication, I can stop to take } \\
\text { the medication even treatment duration has not been completed' }\end{array}$ & $55(32.2)$ & $116(67.8)$ \\
\hline 12 & $\begin{array}{l}\text { 'Once develop side effects of medication, one has to stop the TB } \\
\text { treatment' }\end{array}$ & $49(28.7)$ & $122(71.3)$ \\
\hline
\end{tabular}

Table 6. Comparison of responses for the individual items of the contributing factors of tuberculosis nonadherence

\begin{tabular}{|c|c|c|c|c|c|c|c|}
\hline No & Items & Mean \pm SD & $\begin{array}{c}\text { Strongly } \\
\text { Disagree } \\
\text { n(\%) }\end{array}$ & $\begin{array}{c}\text { Disagree } \\
\mathbf{n}(\%)\end{array}$ & $\begin{array}{c}\text { Neutral } \\
\mathbf{n}(\%)\end{array}$ & $\begin{array}{c}\text { Agree } \\
\text { n(\%) }\end{array}$ & $\begin{array}{c}\text { Strongly Agree } \\
\mathbf{n}(\%)\end{array}$ \\
\hline 1 & $\begin{array}{l}\text { 'If not treated properly, } \\
\text { both medication } \\
\text { susceptible and } \\
\text { resistant types of TB } \\
\text { cause serious health } \\
\text { problems' }\end{array}$ & $3.71 \pm 1.187$ & $9(5.3)$ & $16(9.4)$ & $50(29.2)$ & $37(21.6)$ & $59(34.5)$ \\
\hline 2 & $\begin{array}{l}\text { 'If I don't follow } \\
\text { prevention methods } \\
\text { correctly, TB is highly } \\
\text { contagious disease } \\
\text { which can infect my } \\
\text { whole family members' }\end{array}$ & $4.18 \pm 0.974$ & $2(1.2)$ & $15(8.8)$ & $11(6.4)$ & $65(38)$ & $78(45.6)$ \\
\hline 3 & $\begin{array}{l}\text { 'If we don't complete } \\
\text { our treatment } \\
\text { correctly, we may } \\
\text { again get sick from TB } \\
\text { disease' }\end{array}$ & $4.08 \pm 1.122$ & $7(4.1)$ & $11(6.4)$ & $25(14.6)$ & $45(26.3)$ & $82(48)$ \\
\hline
\end{tabular}




\begin{tabular}{|c|c|c|c|c|c|c|c|}
\hline 4 & $\begin{array}{l}\text { 'TB is the highest killer } \\
\text { infectious disease } \\
\text { globally despite of } \\
\text { having an effective } \\
\text { treatment' }\end{array}$ & $3.57 \pm 1.251$ & $16(9.4)$ & $11(6.4)$ & $57(33.3)$ & $34(19.9)$ & $53(31)$ \\
\hline 5 & $\begin{array}{l}\text { 'Retreatment of TB } \\
\text { disease increases risk } \\
\text { of developing side } \\
\text { effects of medication' }\end{array}$ & $3.16 \pm 1.366$ & $32(18.7)$ & $14(8.2)$ & $56(32.7)$ & $32(18.7)$ & $37(21.6)$ \\
\hline 6 & $\begin{array}{l}\text { 'If symptoms, due to } \\
\text { TB disease disappear } \\
\text { during treatment, } \\
\text { stopping treatment is } \\
\text { possible, even if the } \\
\text { duration of treatment } \\
\text { is not completed' }\end{array}$ & $2.62 \pm 1.347$ & $55(32.2)$ & $25(14.6)$ & $30(17.5)$ & $52(30.4)$ & $9(5.3)$ \\
\hline 7 & $\begin{array}{l}\text { 'TB medications can } \\
\text { weaken our immune } \\
\text { system protection' }\end{array}$ & $2.75 \pm 1.269$ & $40(23.4)$ & $27(15.8)$ & $55(32.2)$ & $33(19.3)$ & $16(9.4)$ \\
\hline 8 & $\begin{array}{l}\text { 'Coming every day } \\
\text { for treatment is not } \\
\text { necessary at all' }\end{array}$ & $3.18 \pm 1.493$ & $44(25.7)$ & $7(4.1)$ & $33(19.3)$ & $49(28.7)$ & $38(22.2)$ \\
\hline 9 & $\begin{array}{l}\text { 'TB treatment } \\
\text { appointment time is } \\
\text { not convenient for } \mathrm{TB} \\
\text { patients' }\end{array}$ & $2.21 \pm 1.273$ & $63(36.8)$ & $54(31.6)$ & $23(13.5)$ & $15(8.8)$ & $15(8.8)$ \\
\hline 10 & $\begin{array}{l}\text { 'Taking TB medication } \\
\text { taking in front of } \\
\text { health care worker/ } \\
\text { treatment supervisor is } \\
\text { not necessary at all' }\end{array}$ & $2.63 \pm 1.346$ & $50(29.2)$ & $30(17.5)$ & $41(24)$ & $33(19.3)$ & $17(9.9)$ \\
\hline 11 & $\begin{array}{l}\text { 'TB patients are not } \\
\text { responsible to take } \\
\text { their TB medication } \\
\text { correctly' }\end{array}$ & $2.27 \pm 1.333$ & $75(43.9)$ & $18(10.5)$ & $49(28.7)$ & $14(8.2)$ & $15(8.8)$ \\
\hline 12 & $\begin{array}{l}\text { 'I do not disclose my } \\
\text { TB disease to anyone } \\
\text { as fear of others } \\
\text { talking bad about me' }\end{array}$ & $3.05 \pm 1.479$ & $37(21.6)$ & $27(15.8)$ & $42(24.6)$ & $21(12.3)$ & $44(25.7)$ \\
\hline 13 & $\begin{array}{l}\text { 'I don't like to be } \\
\text { seen in TB clinic by } \\
\text { somebody who knows } \\
\text { me' }\end{array}$ & $2.18 \pm 1.190$ & $63(36.8)$ & $49(28.7)$ & $36(21.1)$ & $12(7)$ & $11(6.4)$ \\
\hline 14 & $\begin{array}{l}\text { 'People connect TB } \\
\text { disease with HIV; } \\
\text { therefore, I don't like } \\
\text { to come here daily' }\end{array}$ & $2.27 \pm 1.188$ & $60(35.1)$ & $39(22.8)$ & $45(26.3)$ & $19(11.1)$ & $8(4.7)$ \\
\hline 15 & $\begin{array}{l}\text { 'Support from } \\
\text { family, friends and } \\
\text { community is very } \\
\text { important to follow TB } \\
\text { treatment correctly' }\end{array}$ & $3.91 \pm 1.303$ & $13(7.6)$ & $16(9.4)$ & $27(15.8)$ & $33(19.3)$ & $82(48)$ \\
\hline
\end{tabular}




\begin{tabular}{|c|l|l|l|l|l|l|}
\hline 16 & $\begin{array}{l}\text { 'The Healthcare } \\
\text { worker in TB } \\
\text { treatment poor } \\
\text { communication has } \\
\text { made me stop coming } \\
\text { for treatment' }\end{array}$ & $2.02 \pm 1.341$ & $91(53.2)$ & $30(17.5)$ & $20(11.7)$ & $15(8.8)$ \\
\hline
\end{tabular}

Table 7. Comparison of responses for the individual items of the contributing factors of tuberculosis nonadherence

\begin{tabular}{|c|c|c|c|c|c|c|c|}
\hline No & Items & Mean \pm SD & $\begin{array}{c}\text { Strongly } \\
\text { Disagree n(\%) }\end{array}$ & Disagree n(\%) & Neutral n(\%) & $\begin{array}{c}\text { Agree } \\
\text { n(\%) }\end{array}$ & $\begin{array}{c}\text { Strongly Agree } \\
\text { n(\%) }\end{array}$ \\
\hline 17 & $\begin{array}{l}\text { 'I found that } \\
\text { Healthcare } \\
\text { provider is } \\
\text { unfriendly and } \\
\text { avoid seeing } \\
\text { patient' }\end{array}$ & $1.66 \pm 1.133$ & $113(66.1)$ & $29(17)$ & $12(7)$ & $8(4.7)$ & $9(5.3)$ \\
\hline 18 & $\begin{array}{l}\text { 'High cost of } \\
\text { transportation to } \\
\text { healthcare facility } \\
\text { is affecting the } \\
\text { completion of my } \\
\text { TB treatment' }\end{array}$ & $2.74 \pm 1.144$ & $30(17.5)$ & $41(24)$ & $51(29.8)$ & $41(24)$ & $8(4.7)$ \\
\hline 19 & $\begin{array}{l}\text { 'Inability to } \\
\text { gain permission } \\
\text { from workplace } \\
\text { to attend clinic } \\
\text { appointments has } \\
\text { interrupted my TB } \\
\text { treatment' }\end{array}$ & $3.09 \pm 1.386$ & $28(16.4)$ & $33(19.3)$ & $44(25.7)$ & $27(15.8)$ & $39(22.8)$ \\
\hline 20 & $\begin{array}{l}\text { 'My family insisted } \\
\text { me to interrupt } \\
\text { my treatment and } \\
\text { advise me to go for } \\
\text { holy water' }\end{array}$ & $2.25 \pm 1.275$ & $70(40.9)$ & $31(18.1)$ & $36(21.1)$ & $25(14.6)$ & $9(5.3)$ \\
\hline 21 & $\begin{array}{l}\text { 'Traditional } \\
\text { medication is the } \\
\text { one I like to take } \\
\text { than TB drugs' }\end{array}$ & $2.17 \pm 1.256$ & $72(42.1)$ & $34(19.9)$ & $43(25.1)$ & $8(4.7)$ & $14(8.2)$ \\
\hline 22 & $\begin{array}{l}\text { 'My friends } \\
\text { influenced me } \\
\text { not to take TB } \\
\text { treatment' }\end{array}$ & $2.01 \pm 1.181$ & $79(46.2)$ & $45(26.3)$ & $20(11.7)$ & $21(12.3)$ & $6(3.5)$ \\
\hline 23 & $\begin{array}{l}\text { 'My personal } \\
\text { emotional } \\
\text { conditions such } \\
\text { as depression, } \\
\text { motives, sadness, } \\
\text { anger etc. obliged } \\
\text { me to interrupt } \\
\text { my treatment } \\
\text { correctly' }\end{array}$ & $3.15 \pm 1.122$ & $23(13.5)$ & $33(19.3)$ & $24(14)$ & $78(45.6)$ & $13(7.6)$ \\
\hline
\end{tabular}




\begin{tabular}{|c|c|c|c|c|c|c|c|}
\hline 24 & $\begin{array}{l}\text { 'Forgetfulness } \\
\text { is the reason for } \\
\text { interruption of my } \\
\text { TB treatment' }\end{array}$ & $3.26 \pm 1.196$ & $16(9.4)$ & $37(21.6)$ & $24(14)$ & $74(43.3)$ & $20(11.7)$ \\
\hline 25 & $\begin{array}{l}\text { 'TB treatment } \\
\text { could enhance my } \\
\text { quality of life' }\end{array}$ & $2.96 \pm 1.384$ & $42(24.6)$ & $17(9.9)$ & $40(23.4)$ & $49(28.7)$ & $23(13.5)$ \\
\hline 26 & $\begin{array}{l}\text { 'If I take my } \\
\text { medication } \\
\text { properly, I will } \\
\text { not develop } \\
\text { medication } \\
\text { resistant types of } \\
\text { TB' }\end{array}$ & $3.87 \pm 1.208$ & $10(5.8)$ & $14(8.2)$ & $35(20.5)$ & $42(24.6)$ & $70(40.9)$ \\
\hline 27 & $\begin{array}{l}\text { 'If I get treated for } \\
\text { TB correctly, TB } \\
\text { could not spread } \\
\text { to my family } \\
\text { members' }\end{array}$ & $3.97 \pm 1.348$ & $16(9.4)$ & $16(9.4)$ & $13(7.6)$ & $38(22.2)$ & $88(51.5)$ \\
\hline 28 & $\begin{array}{c}\text { 'If I complete } \\
\text { my treatment } \\
\text { correctly, TB could } \\
\text { not relapse to me, } \\
\text { and I am free from } \\
\text { retreatment' }\end{array}$ & $3.31 \pm 1.588$ & $40(23.4)$ & $19(11.1)$ & $17(9.9)$ & $38(22.2)$ & $57(33.3)$ \\
\hline 29 & $\begin{array}{l}\text { 'If I take my } \\
\text { TB medication } \\
\text { properly, my } \\
\text { health will be } \\
\text { recovered slowly' }\end{array}$ & $3.98 \pm 1.090$ & $8(4.7)$ & $12(7)$ & $19(11.1)$ & $69(40.4)$ & $63(36.8)$ \\
\hline 30 & $\begin{array}{c}\text { 'If I take TB } \\
\text { treatment properly, } \\
\text { I will not die } \\
\text { because of TB' }\end{array}$ & $3.99 \pm 1.176$ & $13(7.6)$ & $8(4.7)$ & $16(9.4)$ & $64(37.4)$ & $70(40.9)$ \\
\hline 31 & $\begin{array}{l}\text { 'Community } \\
\text { supports motivate } \\
\text { me to complete } \\
\text { my treatment } \\
\text { correctly' }\end{array}$ & $4.09 \pm 1.283$ & $9(5.3)$ & $20(11.7)$ & 19(11.1) & $22(12.9)$ & $101(59.1)$ \\
\hline 32 & $\begin{array}{l}\text { 'Health care } \\
\text { worker support } \\
\text { and good } \\
\text { communication } \\
\text { motivate me } \\
\text { to complete } \\
\text { my treatment } \\
\text { correctly' }\end{array}$ & $4.28 \pm 1.053$ & $2(1.2)$ & $16(9.4)$ & $17(9.9)$ & $33(19.3)$ & $103(60.2)$ \\
\hline
\end{tabular}


though WHO promotes many schemes to eradicate TB, the existence is more common in malnourished people. Few of the respondents in a study conducted by Cherinet et al. ${ }^{7}$ emphasized that they had experience food shortage during the treatment and hence they failed to comply with regular medications.

In this study, TB is more common in adult who are less than 40 years of age and male. This may be due to the lifestyle changes especially smoking, is very common among the people in this age group. Moreover, the incidences are common in people with secondary level of education who were Malay. Inadequate knowledge about communicable diseases among the particular race plays pivotal role in spreading of the disease. This finding is similar to a study where most of the TB patients are male (47\%), with mean age of 35 years, employed and had completed secondary education $(42.7 \%)^{10}$. Many respondents in study thinking that $\mathrm{TB}$ is most likely caused by a germ through infection, more over they also believe that stress increase the chance of getting infection $^{11-13}$.

Living with more people in the joint family setup, is one of the contributing factors for the spread of the disease. Economy of people also play a role in this spread of disease especially people working private sector for low income and unemployed who unable to meet the day-today expenses in addition to the continuous treatment of TB. Several studies mentioned that financial insecurity of patients or job loss is directly linked with non-adherence to prescribed medication therapy ${ }^{7,11,14}$.

\subsection{Relationship with Knowledge on Tuberculosis and Medication Adherence}

Assessment of knowledge about TB and its contributing factors are utmost important to prevent the spread of disease among the global population. This study was an attempt to gather information about the TB and the factors that contribute the spread of disease among the multiracial society may bring an alert in the future. Knowledge play major role in eradicating the disease through enhanced attitude and perception of particular disease and its complications. The knowledge of TB among the respondents was above the average but not at appreciable level. This is similar to study stated that the total TB knowledge is significantly and positively correlated with medication adherence ${ }^{15-18}$. Government initiation in bringing up the knowledge of TB among its population is highly essential in the current scenario.

\subsection{Relationship with Attitude and Perception on Tuberculosis and Medication Adherence}

Attitude and perception are directly correlating with the perceived knowledge on a particular disease or condition. It is directly proportional to the knowledge and practice. As our respondents scored just above the average on knowledge components, the mean score of respondents on attitude and perception was below 50 percent. This is an alarming situation, the poor attitude and perception towards TB treatment may enhance the spread of disease among the population and this may lead to poor quality of life. People with much more perceived attitude will improve the aim of DOTS therapy in eradicating the disease.

Comparison of knowledge of TB using respondents' demographic characteristics revealed that, there is no significant difference among the age group, sex, educational level, ethnicity, marital and employment status of the respondents. This is in accordance with several other studies, the respondents shown no significant difference in their knowledge of TB and its treatment ${ }^{14,19,20}$. However, the people living in urban area had more knowledge on TB and its treatment which shown a significant reduction in the number of TB cases over years. These problems need to be addressed in emergency basis through appropriate awareness program on TB emphasizing the importance of adherence to TB treatment.

\subsection{Relationship with Knowledge of Contributing Factors of Medication Non-Adherence to Anti-Tuberculosis Therapy}

The knowledge on contributing factors of TB and dropout from TB treatment were compared with the respondents' demography revealed that no significant difference in knowledge of contributing factors across all age group, sex, educational level, ethnicity, marital and employment status of the respondents.

The lack of awareness on contributing factors is a serious problem in the society as it may spread the disease drastically and burden the country's economy. 
Furthermore, it affects the quality-of-life TB patients and increases the length of TB treatment as well as produce resistance to the TB treatment. This can be addressed or nullified through appropriate awareness program to the community where they have lack of knowledge on $\mathrm{TB}$ and its contributing factors. Healthcare providers including physicians, nurses, and pharmacists as well public can play a vital role in spreading the information about the importance of TB treatments and adherence to TB treatments.

Even though people in our study aware of the causative organism of TB and its transmission, they have lack of knowledge in contributing factors especially the role of smoking in TB. Most of the respondents were not aware of the deteriorating problem of smoking in TB. Smoking will adversely affect the mechanism of TB drug and impair the immunity in TB patients. This may delay the curability of the illness and worsen the condition; this may intern reduce the outcome of TB treatment.

Most of the respondents knew the methods of prevention of TB transmission by covering mouth and nose during coughing and sneezing and appropriate sputum dropping. Many were aware of the symptoms, treatment, and the curability of $\mathrm{TB}$, however they had poor knowledge on the transmission of TB through sharing eating utensils, kissing, and shaking hands with TB patients. Having close contact with TB patients, may ease the transmission of TB to one another. Droplet infection, droplet nuclei and close contact with TB patients by shaking hands, kissing, and sexual intercourse may spread the disease to others. Our respondents have poor knowledge on the common method of TB transmission. This is an alarming situation need immediate attention to improve the knowledge among TB patients. The awareness can be created among the TB patients through appropriate education, awareness campaign and counselling. This is contrary to a study where the respondents' TB patients, had adequate knowledge on TB. Knowledge on TB among the tuberculosis patient is very essential to adhere with their TB regimen and to prevent spreading of TB to others.

Only one third of respondents said they need to stop TB medications while experiencing any side effects, whereas almost 70 percent said stopping TB medications during the course of treatment may adversely affect the therapeutic aim of TB management. The treatment for any illness needs to be stopped and seek immediate medical attention while experiencing any unwanted or serious side effects as it may prevent the further worsening of patient's health. Continuing treatment along with serious side effect may endanger patient's life and increase the healthcare costs.

Many of our respondents not aware that if TB is not treated properly it may cause resistant to $\mathrm{TB}$ treatment and the global mortality related to TB infections. More than two-third of the respondents aware if prevention method is not followed properly, TB may affect the entire family member, and also, they will fell sick again from TB disease. More than half of respondents believe that the retreatment of $\mathrm{TB}$ may increase the risk of developing side effects of medication.

Most of the respondents disagree if symptoms of $\mathrm{TB}$ disappear during treatment; stopping treatment is possible even if the duration of treatment is not completed. Continuing TB treatment and completion of TB regimen course is highly essential to prevent further complications and to get complete recovery from TB infection. The findings are similar to a study where half of the respondents agreed to continue the TB treatment and completed the full course of TB regimen ${ }^{7}$. However, in our study many defaulters were observed, and they were not willing to complete the full course of treatment for various reasons. Stopping treatment in its halfway is highly dangerous and it may produce resistant to TB drugs and spread the disease to other healthy people.

Many respondents were not aware and believe that TB treatment can weaken their immune system production. This may be one of the reasons for more defaulters in our study setup. This can be prevented by appropriate education on TB treatment, its benefits and risk of discontinuing TB regimen. Adequate educational and counselling interventions may increase the success rate of completion of TB treatment, but the extent of its benefit depends on the nature of intervention and the population $^{21}$.

We analysed the factors responsible for discontinuing the treatment among the defaulters and found that there are several factors which contributes tremendously to drop out from the current course of treatment. Many were drop out in the beginning of the treatment as they feel that coming every day for treatment is not necessary at all and some feel that the appointment time is not convenient for them. This is similar to a study there were many drop out from the treatment as they feel daily visits impose financial burden to patients and families 
as well as healthcare system in terms of human resource requirements ${ }^{10}$.

Around one third of the respondents feel the transportation cost to the clinic is very high, unable to obtain permission from their workplace to attend DOT clinic and family member interruption during the treatment period to go for holy water and traditional medicines. Also, many respondents in the current set up believe talismans, kavacha and mantra works well for getting speedy recovery from any disease or conditions. This may be due to lack of number of DOTS clinic in the high dense population of Klang Valley, and many believed that traditional medicines work better than conventional allopathic medicine. Religious and ethnic believes also play major role when seeking treatment for any conditions in the locality. Participants in a study believed that getting traditional healing before starting anti-TB medications, during and after TB therapy is effective, took shorter treatment period and keep them away from bad spirits and obtained at affordable costs ${ }^{7}$.

Another study also stated that affordability of travelling daily to the DOTS clinic is a challenge in a context of widespread unemployment ${ }^{10}$. Even though DOTS therapy available at free of cost, the indirect cost of transportation, getting permission from the workplace to avail treatment at DOTS clinics also impact the respondent's adherence to the treatment.

More than half of the respondents feel that taking TB medications in front of HCP is not necessary at all and same number feel that it is not patient's responsibility to take their TB medications correctly. As per WHO, TB patients are advised to take their medications in-front of a healthcare workers to ensure that the medication was administered to the patient every day to prevent further progression of $\mathrm{TB}$ and to ensure patient compliance to their therapy. This is very essential to eradicate the TB disease and make sure the problem is under control among the community. Moreover, taking TB medication regularly and on-time is the responsibility of every $\mathrm{TB}$ patient and the current findings reveal that they lack in knowledge about the TB patient's role in DOT therapy. This must address through extensive awareness program on DOT therapy as well as the role of patients in DOTS therapy.

Many of our respondents do not disclose their condition to anyone as fear of talking bad or bullying about them and many would not like to be seen on the TB clinic by somebody who knows them. This is also one of the contributing factors among the defaulters to drop out from the treatment as they do not want to expose them as a TB patient and public may misinterpret TB with HIV. The participants in a study believed that by adhering to TB treatment bring them out of TB stigma before others knew they had tuberculosis ${ }^{11}$.

Even though, they feel shy to expose them as TB patient to others, they expect adequate support from family, friends, and community. This is similar to a study; the family and social support is quite important predictor for the continuation of TB treatment and to control the spread of disease in the community ${ }^{14}$. Many respondents said they receive adequate support and communication from the healthcare workers, and the HCPs are very friendly. This is very important for the success of DOT therapy and to ensure patient compliance to bring up the health of the TB patients.

Communication plays a vital role in disseminating the information to patients whereas poor communication either from or healthcare provider may lead to nonadherence to anti-TB therapy. A study mentioned that a patient with fair and good communication has higher compliance rate compared to poor communicator. Appropriate communication from the medicine dispensers about the use of medication, associated side effects, and importance of treatment adherence reduces the number of drop out from the treatment ${ }^{19}$.

More than half of the respondents in our study feel depressed, sadness, anger and less motivated to continue the treatment and forgetfulness was one of the main factors to not complying with regular treatment. This is an alarming situation where the people who receive $\mathrm{TB}$ treatment are getting depressed, feel sad and anger. This must be nullified in an emergency basis otherwise; it may bring changes in personal emotional conditions. Psychological counselling can be given to the patients to improve their emotional well-being and to increase medication adherence. This is a similar to study by Karuniawati et al. ${ }^{20}$ where the respondents said forgetfulness, lack of motivation and social support are the main reason for not complying the treatment. However, the compliance rate was doubled after appropriate intervention was given.

Adherence to anti-tubercular therapy is very essential to prevent further progression of the disease and to improve quality of life of TB patients. A regular and periodical awareness programme in terms of campaign or workshops emphasising the complications of $\mathrm{TB}$, 
different types of TB treatment, benefits of adhering to TB treatment, complication of non-adherence, should be provided to TB patients and to their caregivers, which will certainly improve the outcome of TB treatment. There were many problems in the implementation of comprehensive TB intervention program as lack of support from healthcare providers in terms of communication, delivery and administration of medication leads to failure of the program and elevation of non-adherence to treatment. However, nurses can play a vital role in the effective implementation of TB intervention program as they were the immediate point of contact for patients. Conversely, due to lack of time, lack of interest, and fear of infection, the nurses could not turn up. The study recommends all healthcare providers especially nurses to play their vital role in educating the tuberculosis patients about the disease, transmission of infection, management, and importance of compliance to treatment, complications of reinfection and multi-drug resistance. Thereby, we can reduce the number of defaulters and improve quality of life of tuberculosis patients.

The findings may not be the overall reflection as the study was surveyed in a short period of time. This study was conducted in a single organization in teaching hospital, which may limit the generalize of the study findings to all healthcare setting.

\section{Conclusion}

The knowledge, attitude, and perception towards TB treatment among the TB patients who regularly visits the DOTS clinics are moderate to good. However, there are lot of defaulters in the current study site as many TB patients did not follow-up their treatment schedule and drop out in the early phase/month of the TB course. The main reason for non-adherence to TB medications are family, friends, social and community influence during their treatment period. This can be nullified through appropriate educational intervention to $\mathrm{TB}$ patients on regular and periodical basis in the first few weeks of their DOTS therapy.

\section{Acknowledgments}

The authors thank the management of Mahsa University, University of Malaya, University Malaya Medical Centre, and International Medical University for the support, encouragement and providing necessary facilities to carry out this research.

\section{Conflict of Interest}

The researcher has no potential conflict of interest to declare.

\section{Financial Support}

None

\section{References}

1. World Health Organisation. Tuberculosis. WHO. Geneva, Switzerland. 2019. Available from: https://www.who.int/ news-room/fact-sheets/detail/tuberculosis (accessed 15 June 2020).

2. Caminero LJA. A tuberculosis guide for specialist physicians. International Union Against Tuberculosis and Lung Diseases, France, 2003, p. 24. Available from: https:// theunion.org/what-we--do/publications/technical/body/ PUB_TuberculosisGuideForSpecialistPhysicians_Part1_ ENG.pdf (accessed 20 June 2020).

3. Castelnuovo B. A review of compliance to anti tuberculosis treatment and risk factors for defaulting treatment in Sub Saharan Africa. Afr Health Sci. 2010; 10(4):320-4. PMCID: PMC3052808

4. Hirpa S, Medhin G, Girma B, et al. Determinants of multidrug-resistant tuberculosis in patients who underwent first-line treatment in Addis Ababa: a case control study. BMC Public Health. 2013; 13:782. https:// doi.org/10.1186/1471-2458-13-782 PMid:23981845 PMCid:PMC4015150

5. Aziah AM. Tuberculosis in Malaysia: combating the old nemesis. Med J Malaysia. 2004; 59(1):1-3. Available from: http://www.e-mjm.org/2004/v59n1/Tuberculosis_ in_Malaysia.pdfhttp://www.e-mjm.org/2004/v59n1/ Tuberculosis_in_Malaysia.pdf.

6. Awofeso N. Anti-tuberculosis medication side-effects constitute major factor for poor adherence to tuberculosis treatment. Bull World Health Organ. 2008; 86(3):B-D. https://doi.org/10.2471/BLT.07.043802 PMid:18368191 PMCid:PMC2647396

7. Gugssa BC, Shimels T, Bilal AI. Factors contributing to non-adherence with treatment among TB patients in Sodo Woreda, Gurage Zone, Southern Ethiopia: A qualitative study. J Infect Public Health. 2017; 10(5):527-533. https:// doi.org/10.1016/j.jiph.2016.11.018 PMid:28189508 
8. Elbireer S, Guwatudde D, Mudiope P, et al., Tuberculosis treatment default among HIV-TB co-infected patients in urban Uganda. Trop Med Int Health. 2011; 16(8):9817. https://doi.org/10.1111/j.1365-3156.2011.02800.x PMid:21585625

9. Goransson KE, von Rosen A. Patient experience of the triage encounter in a Swedish emergency department. Int Emerg Nurs. 2010; 18(1):36-40. https://doi.org/10.1016/j. ienj.2009.10.001 PMid:20129440

10. Birch S, Govender V, Fried J, et al., Does treatment collection and observation each day keep the patient away? An analysis of the determinants of adherence among patients with Tuberculosis in South Africa. Health Policy Plan. 2016; 31(4):454-61. https://doi.org/10.1093/heapol/czv084 PMid:26384375

11. Woith WM, Larson JL. Delay in seeking treatment and adherence to tuberculosis medications in Russia: a survey of patients from two clinics. Int J Nurs Stud. 2008; 45(8): 1163-74. https://doi.org/10.1016/j.ijnurstu.2007.07.014 PMid:1785480

12. Kessler RC, Andrews G, Colpe LJ, et al., Short screening scales to monitor population prevalences and trends in non-specific psychological distress. Psychol Med. 2002; 32(6):959-76. https://doi.org/10.1017/S0033291702006074 PMid:12214795

13. Vrijens B, De Geest S, Hughes DA, et al., A new taxonomy for describing and defining adherence to medications. Br J Clin Pharmacol. 2012; 73(5):691-705. https://doi. org/10.1111/j.1365-2125.2012.04167.x PMid:22486599 PMCid:PMC3403197

14. Deshmukh RD, Dhande DJ, Sachdeva KS, et al., Social support a key factor for adherence to multidrug-resistant tuberculosis treatment. Indian J Tuberc. 2018; 65(1):41-47. https://doi.org/10.1016/j.ijtb.2017.05.003 PMid:29332647
15. Meda ZC, Lin YT, Sombie I, et al. Medication-adherence predictors among patients with tuberculosis or human immunodeficiency virus infection in Burkina Faso. J Microbiol Immunol Infect. 2014; 47(3):222-32.https://doi. org/10.1016/j.jmii.2013.05.001 PMid:23769812

16. Sagbakken M, Frich JC, Bjune G. Barriers and enablers in the management of tuberculosis treatment in Addis Ababa, Ethiopia: a qualitative study. BMC Public Health. 2008; 8:11. https://doi.org/10.1186/1471-2458-8-11 PMid:18186946 PMCid:PMC2257959

17. Quinn GP, Jacobsen PB, Albrecht TL, et al., Real-time patient satisfaction survey and improvement process. Hosp Top. 2004;82(3):26-32.https://doi.org/10.3200/HTPS.82.3.26-32 PMid:15754859

18. Redding CA, Rossi JS, Rossi SR, et al. Health behavior models. Int Electr J Health Educ. 2000; 3:180-193. https://pdfs. semanticscholar.org/5913/74764a22b4a570906662948e3da0294c03a9.pdf

19. Mishra P, Hansen EH, Sabroe S, et al., Adherence is associated with the quality of professional-patient interaction in Directly Observed Treatment Short-course, DOTS. Patient Educ Couns. 2006; 63(1-2):29-37. https://doi.org/10.1016/j. pec.2005.08.006 PMid:16242297

20. Karuniawati H, Putra ON, Wikantyasning ER, Impact of pharmacist counseling and leaflet on the adherence of pulmonary tuberculosis patients in lungs hospital in Indonesia. Indian J Tuberc. 2019; 66(3):364-369. https:// doi.org/10.1016/j.ijtb.2019.02.015 PMid:31439181

21. Eva Maria G, Librada R, Victoria M, et al., Educational measure for promoting adherence to treatment for tuberculosis, Procedia - Social and BehavioralSciences. 2017;237:705-9. s https://doi.org/10.1016/j.sbspro.2017.02.047 